\title{
Gnosis
}

A Selection of Gnostic Texts

Volume I: Patristic Evidence

Edited by WERNER FOERSTER

English translation edited by R. MCL. WILSON

This work provides a comprehensive selection of patristic texts for the study of Gnosticism, introduced and annotated by distinguished German scholars. A second volume will include extracts from the Nag Hammadi library and from Mandaean literature. $£ 6$

\section{Deuteronomy and the Deuteronomic School}

\section{MOSHE WEINFELD}

The emergence of the 'deuteronomic school' marks a turning point in Israelite literature. The author's thesis is that its origin is to be found in scribal circles of the second half of the seventh century B.C., and he seeks to demonstrate this by an analysis of the literary form employed, by an investigation of the authors' religious ideology, and by a study of their didactic aims and the affinities of their work with wisdom literature. $£ 9$

\section{Essays on Religion and the Ancient World}

\section{ARTHUR DARBY NOCK}

Edited by ZEPH STEWART

The essays and book reviews of Arthur Darby Nock, widely scattered in journals and periodicals, some difficult of access, are here brought together. Two volumes, frontispiece $£ \mathrm{I} 5$. Oxford Classical and Philosophical Monographs

\section{Orthodoxy, Roman Catholicism, and Anglicanism}

\section{METHODIOS FOUYAS}

In this book Archbishop Methodios examines the causes of disagreement between the churches, the growth of dialogue, and the moves towards reconciliation which have developed so remarkably within the last fifty years. $£ 4.50$

\section{The Later Christian Fathers}

A Selection from the Writings of the Fathers from St Cyril of Jerusalem to St Leo the Great Edited and translated by HENRY BETTENSON

The century and a quarter following the Council of Nicaea (A.D. 325) has been called the 'Golden Age of Patristic Literature' and is the period covered in this companion to The Early Christian Fathers (OPB 174, 75p). The writings of Basil the Great, Gregory of Nyssa, Jerome, and other Fathers of the Christian Church are included. 75p Oxford Paperbacks 


\section{JOURNAL OF ECUMENICAL STUDIES}

I) Pioneering articles on all aspects of inter-religious and inter-ideological dialogue.

2) Editorials by the world's most outstanding ecumenical editorial board.

3) Explorations and Responses.

4) Book Reviews of all books of ecumenical interest.

5) Abstracts of articles from over 500 periodicals around the world.

6) Ecumenical events reported in depth from around the world.

7) Précis, discussion, study guides and summaries in four foreign languages after each article.

subscribe to: OVERSEAS $-\$ 8.50$

students $-\$ 4.50$
Journal of Ecumenical Studies Temple University Philadelphia, Pa. I9I22 U.S.A. 


\section{NOTES FOR GONTRIBUTORS}

Contributions and editorial correspondence should be sent to one of the editors: Rev. Professor T. F. Torrance, 37 Braid Farm Road, Edinburgh, eнiо 6le, Scotland; Rev. Professor J. K. S. Reid, Don House, 46 Don Street, Aberdeen, AB2 IUU, Scotland.

Submission of an article is taken to imply that it has not previously been published in English, or is not being considered by another journal for publication in English. In the interests of authors, copyright is normally assigned to the Cambridge University Press. The average length of articles is 5000 words. Although longer articles are accepted, those in excess of 10,000 words cannot be considered.

Contributions (articles and reviews) should be clearly typed in double spacing, and on one side of the paper only. The rule about double spacing applies also to footnotes, which should be used sparingly. Cross-references within the article offered should not be included.

Notes for the editors and instructions for the printer should be attached on separate sheets. Contributors should keep one copy of the typescript for use in correcting proofs.

Contributors from the United States may use U.S. spellings. Greek and Hebrew words need not be transliterated. Capitalisation should be kept to a minimum; and in particular should not be used in pronouns referring to the Deity.

First proofs of articles and article reviews may be read and corrected by contributors, and should normally be returned to the organising editor within ten days of receipt. Correction should be confined to errors of the printer. More extensive correction can be made only with the concurrence of an editor. No proofs of reviews will be sent.

Contributors of articles and article reviews (but not of reviews) receive 25 free offprints. Extra copies may be bought according to an agreed scale of charges, provided that thcse are ordered at the time of returning corrected proofs.

\section{PERMISSIONS}

For permission to reproduce material from Scottish fournal of Theology please apply to the London or New York office of Cambridge University Press. 


\section{GONTENTS}

The Old Testament in the Age of the Greek Apologists A.D. I30-18o, by W. H. C. Frend (Glasgow)

Anselm and the Faithfulness of God, by

Peter M. Schmiechen (Elinhurst, Illinois)

Galvin and Experience, by Charles Partee

(Storm Lake, Iowa)

Last Thoughts of Karl Barth, by Herber't Hartwell (London)

The Meaning of $\Sigma a ́ p \xi$ in I Corinthians 5.5, by

Antriony G. Thiselton (Sheffield)

204

\section{REVIEWS}

BAUER (ed.): Bauer Encyclopedia of Biblical Theology, Vols. 1-3 229

EBELING: Lutherstudien, Bd. I

CUNLIFFE-JONES: Christian

Theology since 1600

BERKOUWER: $\mathrm{Sin}$

AHLSTROM: A Religious History of the American People

MAYOR: The Lord's Supper in

Early English Dissent

DEssain (ed.): The Letters and

Diaries of John Henry

Newman

LINDBLOM : Erwägungen zur

Herkunft der Josianischen

Tempelurkunde

FRIEDRICH (ed.): Theological

Dictionary of the New

Testament, Vol. VIII

232

233

238

240
LOHSE: A Commentary on the Epistles to the Colossians and to Philemon

MOORE (ed.): I and II

Thessalonians. GUTHRIE (ed.):

Galatians

CHARLOT: New Testament

Disunity

MORGAN (ed.): Unity: The Next

234 Step? wenham: Renewal and

Unity of the Church in

England

236 GREEN and IRISH: Death

Education. VERE: Voluntary

Euthanasia. BRowNE: Human

Ecology

RAMSEy: The Christian Priest

Today

BRUCE and DUFFIELD (eds.): Why

Not? Priesthood and the

Ministry of Women

GARDNER (ed.): The Faber Book of Religious Verse
244

245

247

247

$24^{8}$

252

$2 \dot{5} 4$

(C) Cambridge University Press, 1973

Printed in Great Britain by R. \& R. Glark, L'd., Edinburgh 